\title{
Factors associated with sexually transmitted infections in sugarcane cutters: subsidies to caring for*
}

\author{
Juliana Pontes Soares ${ }^{1}$ \\ (1D) https://orcid.org/0000-0001-6203-9937 \\ Sheila Araújo Teles ${ }^{2}$ \\ (D) https://orcid.org/0000-0002-7059-4241 \\ Karlla Antonieta Amorim Caetano ${ }^{2}$ \\ (1) https://orcid.org/0000-0003-4818-4753 \\ Thaynara Ferreira Amorim ${ }^{3}$ \\ (iD) https://orcid.org/0000-0001-8689-3281 \\ Maria Eliane Moreira Freire 4 \\ (D) https://orcid.org/0000-0002-0305-4843 \\ Jordana de Almeida Nogueira ${ }^{4}$ \\ (1) https://orcid.org/0000-0002-2673-0285 \\ Brunna Rodrigues de Oliveira ${ }^{5}$ \\ (1) https://orcid.org/0000-0002-5697-9727 \\ Oriana Deyze Correia Paiva Leadebal ${ }^{4}$ \\ (D) https://orcid.org/0000-0002-3342-8746 \\ Patricia da Silva Araújo ${ }^{6}$ \\ (D) https://orcid.org/0000-0002-9273-3978 \\ Ana Cristina de Oliveira e Silva ${ }^{4}$ \\ (D) https://orcid.org/0000-0001-8605-5229
}

Objective: to estimate the prevalence of Sexually Transmitted Infections (STIs) and associated factors in sugarcane cutters. Method: a cross-sectional, analytical study with 937 sugarcane cutters from Paraíba and Goiás, states of Brazil, respectively. An outcome variable was the positive results in some rapid tests for HIV, syphilis, hepatitis B and C. Bivariate and multiple analyses were performed to identify the association between these infections and sociodemographic and behavioral variables. Results: all participants were male, most were young adults and had low schooling. Prevalence of STI was estimated at $4.1 \%$ (95\% CI: 3.0-5.5). According to multiple regression analysis, the variables age over 40 years (OR 5.0; CI 95\%: 1.8-14), alcohol consumption (OR 3.9; CI 95\%: 1.3-11.9), and illicit drugs (OR 2.9; CI 95\%: 1.36.3) were factors associated with the STIs investigated. On the other hand, having some religion (OR 0.4; CI 95\%: 0.2-0.8), and work in the Midwest Region (OR 0.4; CI 95\%: 0.2-0.9) were factors negatively associated with these infections. Conclusion: presence of risk behaviors for STI among sugarcane cutters. Screening for these infections in groups of rural workers is essential for early diagnosis and breaking the chain of transmission.

Descriptors: Sexually Transmitted Diseases; Prevalence; Vulnerable Populations; Rural Population; Nursing Care; Risk Factors.

\section{How to cite this article}

Soares JP, Teles SA, Caetano KAA, Amorim TF, Freire MEM, Nogueira JA, Oliveira BR, Leadebal ODCP, Araújo PS, Silva ACO. Factors associated with sexually transmitted infections in sugarcane cutters: subsidies to caring for. Rev. Latino-Am. Enfermagem. 2020;28:e3306. [Access Available in: DOI: http://dx.doi.org/10.1590/1518-8345.3425.3306. month day year 


\section{Introduction}

Worldwide, approximately one million people acquire some sexually transmitted infection (STI) each day, with an annual forecast of 357 million new curable infections. There are more than 20 microorganisms causing STIs, among those responsible for asymptomatic infections are hepatitis $B$ virus (HBV), hepatitis $C$ virus (HCV), human immunodeficiency virus (HIV) and the Treponema pallidum, the aetiological agent of syphilis ${ }^{(1)}$.

The World Health Organization (WHO) has estimated 257 million and 71 million people chronically infected with HBV and HCV in 2015, respectively. These viruses are responsible for more than one million deaths per year and are the cause of acute and chronic liver disease, including cirrhosis and hepatocellular carcinoma(2). Brazil is considered a country of low endemicity for viral hepatitis $B$ and $C$, however, considering its population size, the absolute number of infected individuals is significant. According to the epidemiological bulletin for $2019,233,027$ cases of hepatitis B and 359,673 cases of hepatitis C were reported from 1999 to $2018^{(3)}$.

Globally, about 37.9 million people were living with HIV in 2018, with 1.7 million new infections ${ }^{(4)}$. In Brazil, the HIV epidemic is of the concentrated type, that is, it mainly affects key populations. Most cases are detected in urban regions, although a gradual process of an epidemic's growth in the countryside has been observed in the country. From 1980 to June 2019, 966,058 cases of AIDS were notified in the country. In 2018, 43,941 new cases of HIV infection were registered(5).

In 2016, the number of syphilis cases in people aged 15 to 49 was estimated at 6.3 million, with a global prevalence of $0.5 \%{ }^{(6)}$. In Brazil, in recent years, there has been an increase in the number of people infected by $T$. pallidum. In 2017, the detection rate of acquired syphilis was 59.1 cases/100,000 inhabitants, while in 2018 this rate reached 75.8 cases $/ 100,000$ inhabitants, an increase of almost 17 new cases $/ 100,000$ inhabitants in just one year(7). HIV, HBC, HCV, and Treponema pallidum infections are important causes of morbidity and mortality, and their elimination as global public health problems represents WHO goals for the achievement of the United Nations Agenda 2030 Sustainable Development Goals ${ }^{(8-10)}$.

In general, men are more susceptible to risk behavior and seek health services less when compared to women, especially those men belonging to more vulnerable populations with less education and purchasing power, including those living in rural areas ${ }^{(11)}$.

Male norms such as competitiveness, strength, power, and self-confidence can interfere with how a man whether commits or not to his own health ${ }^{(12)}$. Also, beyond gender issues, the operation hours of health facilities often coincide with the working hours of individuals, reducing their opportunities to participate in disease prevention and knowledge activities, and of their health situation and treatment $^{(13)}$. In this context, screening and treating STIs in men is an important strategy for interrupting the chain of transmission of these infections, particularly among those who possibly have less access to health services, such as male field workers.

Brazil is one of the largest producers of sugarcane and alcohol in the world. Although mechanization of cane cutting is gradually replacing manual cutting, this technology has not yet fully reached some regions such as the Northeast and Midwest ${ }^{(14)}$. Manual sugarcane cutting is a strenuous job performed by men of low education and income. These individuals work under a productivity regimen and, in order to obtain better wage earnings, they submit themselves to an excessive workload. The seasonal nature of cane harvesting favors the migration of workers to harvesting regions ${ }^{(15)}$. Studies show several health problems related to sugarcane harvesting, among the most cited are respiratory problems, decreased kidney function, and repetitive strain injury ${ }^{(16-18)}$. However, there is no information on sexually transmitted infections in this population of rural, seasonal-migrant males.

In a previous publication, the prevalence of HIV, HBV, $\mathrm{HCV}$ and syphilis infections in the cane cutter population and analysis of factors associated with exposure to HBV were presented(19). However, considering that these infections present common forms of transmission, the objective of the present study was to identify variables associated with these STIs (HIV, HBV, HCV, and syphilis), which can be used as indicators of vulnerability in sugarcane cutters operating in alcohol and sugar mills located in the Northeast and Midwest of Brazil.

\section{Method}

This is an observational, cross-sectional study carried out in sugarcane mills in the states of Paraíba and Goiás, in Northeast and Midwest regions of Brazil, respectively. Data collection was conducted from February to September 2016.

During the study period, there were 38 and 9 sugar and alcohol mills in Goiás and Paraíba, respectively ${ }^{(20)}$. For the study, we considered the mills that performed predominantly manual harvesting of sugarcane and that were in the harvesting period. In Paraíba, data collection was carried out at the largest plant in the region, and in Goiás at four plants.

The target population of this study was rural workers, manual sugarcane cutters. All individuals 
aged 18 years or older, who performed manual cutting of sugarcane in alcohol and sugar mills in the State of Paraíba and Goiás were included. The minimum sample needed, considering a statistical power of $80 \%$ $(\beta=20 \%)$, significance level of $5 \%(a<0.05)$, accuracy of $0.5 \%, 1.5$ drawing effect, and prevalence for anti-HIV of $0.39 \%{ }^{(21)}$ was 895 participants.

In general, cane cutters are distributed in teams of 30 to 50 men to perform the cane cutting. The recruitment of individuals was done in the cane field itself, during rest periods, sequentially and according to the arrival of the worker at the resting place. All eligible workers were invited to participate in the study and informed about its importance, objectives, risks, and benefits of participation, as well as the freedom to leave the study at any time. For individuals who wished to participate, the Informed Consent Form (ICF) was offered for reading and signing. In cases of illiterate ones, the ICF was read to the cane cutter and a witness, and the participant's signature was fingerprinted.

Upon acceptance by the participant, the interview was conducted right in the sugarcane field, maintaining a minimum comfortable distance to respond with privacy. For this, we used a structured script adapted from the instrument used in the Research of Knowledge, Attitudes, and Practices in the Brazilian Population (22), containing social demographic data and possible risk behaviors for the STIs investigated.

At the end of the interview, the participants were referred for rapid tests (RT) for HBV [HBsAg (Vikia HBsAg Biomerieux, France)], HCV [anti-HCV (Alere, Standard Diagnostics Inc, Republic of Korea)], syphilis [anti- $T$. pallidum (Alere Syphilis, Republic of Korea)] and HIV [anti-HIV-1 and 2 (screening - ABON HIV Tri-Line, Abon Biopharm, China; confirmatory - Bioeasy HIV, Republic of Korea)] as instructed by the manufacturers. We used rapid tests made available by the Brazilian Ministry of Health, through partnerships with the regional Health Secretariats. The interviewers and rapid test team were trained and prepared to perform these stages of the study.

For the analysis of the interview data and the rapid tests, the statistical STATA program version
13.0 (StataCorp., CollegeStation, TX) was adopted. The descriptive analysis was performed by frequency distribution, mean and standard deviation. We considered STI outcome the positive results in some of the tests performed. Prevalence was calculated with a $95 \%$ confidence interval (95\% CI). Chi-squared and Fisher's Exact tests were used to test differences in proportions. To estimate the odds ratio, the variables that presented a $\mathrm{p}$-value $<0.20$ were included in a logistic regression model(23), using the forward procedure for selecting the variables. P-values $<0.05$ associations were considered statistically significant The quality of the model adjustment was carried out through the Hosmer-Lemershow test $(p=0.7007)$ and the ROC curve showed an area under the 0.75 curve.

This study was approved by the Research Ethics Committee of the Lauro Wanderley University Hospital of the Federal University of Paraíba according to protocol 1507737 and by the Research Ethics Committee of the Federal University of Goiás, according to protocols 1507737 and 042796/20, respectively. The ethical principles that guide research involving human beings, as described and established in Resolution n0466/2012 of the National Health Council, were respected at all stages of research(24). Those individuals who tested positive for any infection were referred for diagnosis and/or treatment confirmation.

\section{Results}

Of the total number of participants $(n=937), 301$ worked in sugar cane and alcohol mills in Paraíba and 636 in Goiás. The mean age was 35.4 years $(S D=9.2$ years) and most were under 40 . We found that $47.4 \%$ declared schooling of fewer than five years. Regarding the place of birth, $85.7 \%$ were native of the Northeast Region. The average monthly income was $R \$ 1,801.00$ $(\mathrm{SD}=\mathrm{R} \$ 438.00)$, and more than two thirds (71.2\%) of the sugarcane cutters said they had religion (Table 1 ).

By means of rapid tests, a prevalence in the set of these markers was estimated at $4.1 \%$ (95\% CI: $3.0-$ $5.5)$, that is, out of every 100 sugarcane cutters, four were positive to at least one of the STI.

Table 1 - Sociodemographic characteristics of sugarcane cutters in the states of Paraíba and Goiás (N = 937), Brazil, 2016

\begin{tabular}{lcccc} 
& Variables & Paraíba (\%) & Goiás (\%) & \multirow{2}{*}{ Total (\%) } \\
\cline { 2 - 3 } & & $\mathbf{n}=\mathbf{3 0 1}$ & $\mathbf{n = 6 3 6}$ & \\
\hline Age $^{*}$ 35.4(9.2) & & & & \\
$\leq 29$ & $76(25.2 \%)$ & $190(29.9 \%)$ & $266(28.4 \%)$ \\
$30-39$ & $121(40.2 \%)$ & $259(40.7 \%)$ & $380(40.5 \%)$ \\
$\geq 40$ & $104(34.6 \%)$ & $187(29.4 \%)$ & $291(31.1 \%)$ \\
\hline
\end{tabular}


Table 1 - (continuation)

\begin{tabular}{|c|c|c|c|}
\hline \multirow{2}{*}{ Variables } & Paraíba (\%) & Goiás (\%) & \multirow{2}{*}{ Total (\%) } \\
\hline & $n=301$ & $n=636$ & \\
\hline \multicolumn{4}{|l|}{ Schooling* $5.2(3.6)^{\dagger}$} \\
\hline$\leq 4$ & $183(60.9 \%)$ & $261(41.0 \%)$ & $444(47.4 \%)$ \\
\hline$>4$ & $118(39.1 \%)$ & $375(59.0 \%)$ & $493(52.6 \%)$ \\
\hline \multicolumn{4}{|l|}{ Marital status } \\
\hline Married/Stable union & $274(91.0 \%)$ & $452(71.0 \%)$ & $726(77.5 \%)$ \\
\hline Single/Separated/Widow/Widower & $27(9.0 \%)$ & $184(29.0 \%)$ & $211(22.5 \%)$ \\
\hline \multicolumn{4}{|l|}{ Region of origin } \\
\hline Northeast & $301(100.0 \%)$ & $502(79.0 \%)$ & $803(85.7 \%)$ \\
\hline Midwest & - & $129(20.3 \%)$ & $129(13.8 \%)$ \\
\hline North & - & $4(0.6 \%)$ & $4(0.4 \%)$ \\
\hline Southeast & - & $1(0.1 \%)$ & $1(0.1 \%)$ \\
\hline \multicolumn{4}{|l|}{ Income ${ }^{\ddagger} 1801(438)^{\dagger}$} \\
\hline$\leq 1500$ & $139(46.2 \%)$ & $187(29.4 \%)$ & $326(34.8 \%)$ \\
\hline $1500-2000$ & $137(45.5 \%)$ & $275(43.2 \%)$ & $412(44.0 \%)$ \\
\hline$>2000$ & $25(8.3 \%)$ & $174(27.4 \%)$ & $199(21.2 \%)$ \\
\hline \multicolumn{4}{|l|}{ Religion } \\
\hline No & $91(30.2 \%)$ & $179(28.4 \%)$ & $270(28.8 \%)$ \\
\hline Yes & 210 (69.8\%) & 457 (71.6\%) & $667(71.2 \%)$ \\
\hline
\end{tabular}

*years; ${ }^{+}$mean (standard deviation); ${ }^{\ddagger}$ Reais $(\mathrm{R} \$) /$ per month

The bivariate analysis showed a statistically significant association between positivity for some investigated STI and age, having a religion, reporting has had same-sex sexual intercourse, illicit drug use. These variables and those with a p-value $<0.20$ (schooling, work region, number of sexual partnerships and prison experience) were included in a multiple logistic regression model, with the variables age ( $\geq 40$ years; OR: $5 ; 95 \% \mathrm{CI}: 1,8-14$ ), religion (OR: $0.4 ; 95 \% \mathrm{CI}: 0.2-0.8$ ), Midwest Region (OR: $0.4 ; 95 \% \mathrm{CI}: 0.2-0.9$ ), use of illicit drugs (OR: $2.9 ; 95 \% \mathrm{CI}$ : 1.3-6.3) and alcohol use (OR: 3.9;95\% CI: 1.3-11.9) were significantly associated with the presence of STI.

Table 2 - Bivariate and multiple analysis of factors associated with Sexually Transmitted Infections in sugarcane cutters in Paraíba and Goiás ( $\mathrm{N}=937)$, Brazil, 2016

\begin{tabular}{|c|c|c|c|c|c|}
\hline & \multirow{2}{*}{\multicolumn{2}{|c|}{$\begin{array}{c}\text { Bivariate Analysis } \\
S T I(n=937)\end{array}$}} & \multirow{4}{*}{$p$} & \multirow{3}{*}{$\begin{array}{c}\text { Multiple Analysis } \\
(n=937) \\
\mathrm{OR}^{*}(95 \% \mathrm{Cl})^{\dagger}\end{array}$} & \multirow{4}{*}{$p$} \\
\hline & & & & & \\
\hline & Positive $(n=38)$ & Negative $(n=899)$ & & & \\
\hline & n (\%) & n (\%) & & & \\
\hline \multicolumn{6}{|l|}{ Age (years old) } \\
\hline$\leq 29$ & $5(1.9 \%)$ & $261(98.1 \%)$ & & $1^{\ddagger}$ & \\
\hline 30 to 39 & $13(3.4 \%)$ & $367(96.6 \%)$ & 0.248 & $2.2(0.8-6.4)$ & 0.138 \\
\hline$\geq 40$ & $20(6.9 \%)$ & $271(93.1 \%)$ & 0.008 & $5(1.8-14)$ & 0.002 \\
\hline \multicolumn{6}{|l|}{ Schooling (years) } \\
\hline$\leq 4$ & $22(4.95 \%)$ & $422(95.05 \%)$ & & 1 & \\
\hline$>4$ & $16(3.25 \%)$ & $477(96.75 \%)$ & 0.185 & $1.1(0.5-2.3)$ & 0.757 \\
\hline \multicolumn{6}{|l|}{ Marital status } \\
\hline Married/Stable union & $27(3.7 \%)$ & $699(96.3 \%)$ & & & \\
\hline Single/Separated/Widow/Widower & $11(5.2 \%)$ & $200(94.8 \%)$ & 0.333 & & \\
\hline \multicolumn{6}{|l|}{ Have a religion } \\
\hline No & $17(6.3 \%)$ & $253(93.7 \%)$ & & $1^{\ddagger}$ & \\
\hline Yes & $21(3.2 \%)$ & $646(96.8 \%)$ & 0.027 & $0.4(0.2-0.8)$ & 0.015 \\
\hline \multicolumn{6}{|l|}{ Work region } \\
\hline Northeast & $16(5.3 \%)$ & $285(94.7 \%)$ & & $1^{\ddagger}$ & \\
\hline Midwest & $22(3.5 \%)$ & $614(96.5 \%)$ & 0.179 & $0.4(0.2-0.9)$ & 0.028 \\
\hline
\end{tabular}




\begin{tabular}{|c|c|c|c|c|c|}
\hline & \multirow{2}{*}{\multicolumn{2}{|c|}{ Bivariate Analysis }} & \multirow{4}{*}{$p$} & \multirow{3}{*}{$\begin{array}{c}\text { Multiple Analysis } \\
(\mathrm{n}=937) \\
\mathrm{OR}^{*}(95 \% \mathrm{Cl})^{\dagger}\end{array}$} & \multirow{4}{*}{$p$} \\
\hline & & & & & \\
\hline & Positive $(n=38)$ & Negative $(n=899)$ & & & \\
\hline & $\mathrm{n}(\%)$ & n (\%) & & & \\
\hline \multicolumn{6}{|c|}{ Has shared housing during work } \\
\hline No & $30(4.6 \%)$ & $630(95.4 \%)$ & & & \\
\hline Yes & $8(2.9 \%)$ & $269(97.1 \%)$ & 0.241 & & \\
\hline \multicolumn{6}{|c|}{ Age of first sexual intercourse (years) } \\
\hline $7-15$ years & $19(4.1 \%)$ & $444(95.9 \%)$ & & & \\
\hline$>=16$ years old & $19(4 \%)$ & $455(96 \%)$ & 0.941 & & \\
\hline \multicolumn{6}{|c|}{ Same-sex sexual intercourse report } \\
\hline No & $33(3.7 \%)$ & $852(96.3 \%)$ & & 1 & \\
\hline Yes & $5(9.6 \%)$ & $47(90.4 \%)$ & 0.036 & $1.9(0.6-5.8)$ & 0.252 \\
\hline \multicolumn{6}{|l|}{ History of sexual abuse } \\
\hline No & $37(4 \%)$ & $887(96 \%)$ & & & \\
\hline Yes & $1(7.7 \%)$ & $12(92.3 \%)$ & 0.503 & & \\
\hline \multicolumn{6}{|c|}{ Number of sexual partnerships in the last 12 months } \\
\hline$<=1$ partner & $19(3.4 \%)$ & $545(96.6 \%)$ & & 1 & \\
\hline$>=2$ partners & $19(5.1 \%)$ & $354(94.9 \%)$ & 0.19 & $1.7(0.8-3.3)$ & 0.144 \\
\hline \multicolumn{6}{|c|}{ Has used condom in the last 12 months } \\
\hline Yes (always, sometimes) & $22(4.4 \%)$ & $479(95.6 \%)$ & & & \\
\hline Never & $16(3.7 \%)$ & $420(96.3 \%)$ & 0.577 & & \\
\hline \multicolumn{6}{|l|}{ Has used illicit drugs in life } \\
\hline No & $28(3.4 \%)$ & $783(96.6 \%)$ & & $1^{\ddagger}$ & \\
\hline Yes & $10(7.9 \%)$ & $116(92.1 \%)$ & 0.018 & $2.9(1.3-6.3)$ & 0.008 \\
\hline \multicolumn{6}{|l|}{ Alcohol use (current) } \\
\hline No & $4(1.9 \%)$ & $210(98.1 \%)$ & & $1^{\ddagger}$ & \\
\hline Yes & $34(4.7 \%)$ & $689(95.3 \%)$ & 0.065 & $3.9(1.3-11.9)$ & 0.017 \\
\hline \multicolumn{6}{|l|}{ Prison experience } \\
\hline No & $32(3.8 \%)$ & $815(96.2 \%)$ & & 1 & \\
\hline Yes & $6(6.7 \%)$ & $84(93.3 \%)$ & 0.187 & $1.1(0.4-3)$ & 0.826 \\
\hline \multicolumn{6}{|c|}{ Presence of tattoo and/or piercing } \\
\hline No & $33(4 \%)$ & $798(96 \%)$ & & & \\
\hline Yes & $5(4.7 \%)$ & $101(95.3 \%)$ & 0.714 & & \\
\hline
\end{tabular}

\section{Discussion}

The rural population in Brazil lives, generally, in conditions of extreme poverty, isolation and in regions marked by socioeconomic inequalities and health vulnerabilities(25). Especially, manual sugarcane cutters bear unhealthy working conditions, long working hours, high migratory flow and wages conditioned to productivity(26). In this context, these workers have characteristics that expose them to various health hazards, including sexual infections. Few studies have been developed addressing the health status of sugarcane cutters ${ }^{(26-27)}$, and in the context of sexually transmitted infections, this is the first research that presents data on the prevalence of STIs and associated factors.

In line with other studies developed with manual sugarcane cutters, our population was marked by men, young and with few schooling years ${ }^{(27-28)}$. Young men predominance in this scenario is related to the type of work in sugarcane fields, which requires great effort and physical stamina(27). On the other hand, the low schooling evidences the socioeconomic conditions of these 
workers $^{(11)}$, and it has been related to less knowledge, less concern about health care, and consequently greater vulnerability in these individuals ${ }^{(29)}$. Gender and education represent explanatory variables for different risky sexual behaviors(29-30).

In the present study, we observed that 4.1\% (95\% $\mathrm{CI}: 3.0-5.5)$ of cane cutters presented tests reagent on at least one of the STIs (HIV, syphilis, hepatitis B and C). Given the lack of studies showing the prevalence of a set of infections investigated in sugarcane cutters, data from this study were compared with those from other investigations conducted in rural populations, in which specific STIs were evaluated; and this highlights the need for programs to prevent and control these infections in rural workers. A national survey conducted in Rwanda, an African country, with 12,361 individuals living in rural areas, showed a prevalence of syphilis of $0.9 \%$. (IC 95\%: $0.7-1.1)^{(31)}$. In rural municipalities of China, it was observed that 3.0\% (95\% CI: 2.4-3.6) e $3.2 \%$ (95\% CI: 2.6-3.8) of male clients of sex workers were positive for HIV and syphilis, respectively(32).

In Brazil, in the rural region of São Paulo (Cássia dos Coqueiros), 1001 rural workers were investigated and $0.4 \%$ (95\% CI:0.2-1.0) were positive for anti-HCV and $0.1 \%$ (95\% CI:0.0-0.6) for HBsAg( ${ }^{(33)}$. While a study conducted in Minas Gerais, with 757 residents of rural communities in Ouro Preto, detected rates for syphilis of $5.3 \%$ (95\% CI:3.9-7.1), hepatitis B of $0.3 \%$ (95\% CI:0.1-1.0), hepatitis C of $0.4 \%$ (95\% CI:0.1-1.2) and no case of HIV was identified among the individuals investigated(34).

As in other STI studies, a positivity gradient for STIs was observed with advancing age, with individuals over 40 years of age presenting five times more chance of positivity for any of the infections investigated when compared to those under 30 years of age. This result probably reflects lifetime exposures(35-36).

One finding that drawn attention was the high frequency of alcohol and illicit drug consumption, and as observed in other studies ${ }^{(37-38)}$, these variables are positively associated with STIs. Almost all cane cutters reported consumption of alcohol and $13.4 \%$ of illicit drugs in their lives. The consumption of these drugs seems to be a reality among sugarcane cutters, often stimulated to withstand the excessive workload in the field(39). Furthermore, the consumption of alcohol often promotes the individual's disinhibition, in addition to reducing his or her memory, which contributes to reducing the perception of risk ${ }^{(40)}$. In fact, their daily consumption has been associated with inconsistent condom use and multiplicity of sexual partnerships ${ }^{(41)}$. Similarly, illicit drug use can encourage sexual risk behavior among users, making them vulnerable to
STIs ${ }^{(42)}$. Such behaviors contribute to the acquisition and maintenance of the STIs' transmission chain and constitute a serious public health problem.

Some studies have shown that practicing a religion reduces risk behaviors for STI by establishing behavioral norms for its followers ${ }^{(43-45)}$. In the present study, individuals who reported some religion presented lower positivity to STI, and this variable was negatively associated with these infections, reinforcing this hypothesis(46-47).

Sugarcane cutters in activity in the Midwest Region presented a $60 \%$ lower chance of positivity to the group of investigated STIs. Most sugarcane cutters in Goiás (79\%) are seasonal migrants from cities in the Northeast Region of the country, and have higher education levels than those from Paraíba $(p<0.001$; data not presented). Thus, this condition may have contributed to the present finding, considering that education is a determining factor for social vulnerability, since it influences attitudes, risk recognition, adherence to disease prevention and treatment(48-49).

Some limitations of this study must be considered. First, this is a cross-sectional study, i.e., it does not allow causal inference; however, it should be noted that the situational diagnosis of the population is the first step to propose interventions. Also, we considered for the presence of STIs the positivity for four sexual infections by means of rapid tests. It is known that several other pathogens are important in the sexual context, on the other hand, analyzing the predominance and silent behavior of HIV, Treponema pallidum, HBV, and HCV, it is justified the selection of these agents to compose the outcome variable of this study.

Finally, intimate questions (sexual and life habits) were used during the interview and many participants may have felt embarrassed to talk about these behaviors, and issued unreliable answers, however, at all times of the interview they were informed about the confidentiality of the information, for greater confidence in the answers received.

\section{Conclusion}

The results show a prevalence of STIs in sugarcane cutters similar to rates in other rural communities around the world and Brazil. On the other hand, it points out risk behaviors for STI common to urban regions, such as alcohol and illicit drugs consumption. This scenario contributes to the risk of STI transmission and consequently the maintenance of the transmission chain of these infections. Thus, we recommend that sexual prevention integrate the actions to promote the health of sugarcane cutters in Brazil. Currently, sugaralcohol companies are encouraged to ensure better 
working conditions, and among the various strategies are initiatives aimed at promoting workers' health and safety. Rapid testing, together with a comprehensive approach to STIs, is an urgent and effective proposal to be implemented in this context of rural worker health prevention, as it provides a quick, easy and efficient way to prevent and diagnose STIs.

\section{References}

1. World Health Organization. [Internet]. Sexually Transmitted Infections (IST) 2015. [cited 2018 Apr, 9]. Available from: http://www.who.int/mediacentre/ factsheets/fs110/en/

2. World Health Organization. Global Hepatitis Report 2017. Geneva: World Health Organization; 2017. Licence: CC BY-NC-SA 3.0 IGO. Available from: https://apps.who.int/iris/bitstream/hand le/10665/255016/9789241565455-eng.pdf?sequence $=1$

3. Ministério da Saúde (BR). Boletim epidemiológico de hepatites virais. [Internet]. 2019. [Acesso em 9 abr 2018). Disponível em: http://www.aids.gov.br/ptbr/pub/2019/boletim-epi

4. United Nations. UNAIDS data 2019. [Internet]. [cited Jul 11, 2019] Available from: https://www.unaids.org/sites/ default/files/media_asset/2019-UNAIDS-data_en.pdf.

5. Ministério da Saúde (BR). Boletim Epidemiológico HIV/Aids 2019. [Internet]. [Acesso em 11 jul 2019]. Disponível em: http://www.aids.gov.br/pt-br/pub/2019/ boletim-epidemiologico-de-hivaids-2019.

6. Rowley J, Hoorn SV, Korenromp E, Low N, Unemo M, Abu-Raddad LJ, et al. Chlamydia, gonorrhoea, trichomoniasis and syphilis: global prevalence and incidence estimates, 2016. Bull World Health Organ. 2019 Aug;97(8):548-62P. doi: http://dx.doi.org/10.2471/BLT.18.228486

7. Ministério da Saúde (BR). Boletim Epidemiológico de Sífilis. [Internet]. 2019. [Acesso em 11 jul 2019]. Disponível em: http://www.aids.gov.br/pt-br/pub/2019/ boletim-epidemiologico-sifilis-2019

8. World Health Organization. Global health sector strategy on sexually transmitted infections 2016-2021 TowardsendingSTIs. [Internet]. 2016. [citedFeb 19, 2020]. Availablefrom: https://www.who.int/reproductivehealth/ publications/rtis/ghss-stis/en/

9. World Health Organization. Global health sector strategy on HIV 2016-2021 - Towards ending AIDS. [Internet]. 2016. [cited Feb 19, 2020]. Available from: https://apps. who.int/iris/bitstream/handle/10665/246178/WHO-HIV2016.05-eng.pdf; jsessionid =A760E6C8E974E403518AA D09F961C778? sequence $=1$

10. World Health Organization. Global health sector strategy on viral hepatitis 2016-2021 Towards Ending Viral Hepatitis. [Internet]. 2016. [cited Feb 19 2020]. Available from: https://apps.who.int/iris/bitstream/handle/10665/246177/ WHO-HIV-2016.06-eng.pdf?sequence $=1$

11. Thorpe RJ Jr, Halkitis PN. Biopsychosocial determinants of the health of boys and men across the lifespan. Behav Med. 2016 Jul-Sep;42(3):129-31. doi: https://doi.org/10.1080/08964289.2016.1191231

12. Rosu MB, Oliffe JL, Kelly MT. Nurse practitioners and men's primary health care. Am J Mens Health. 2017 Sep;11(5):1501-11. doi: 10.1177/1557988315617721 13. Ministério da Saúde (BR). Política Nacional de Atenção Integral à Saúde do Homem (Princípios e Diretrizes). [Internet]. 2008. [Acesso em 11 jul 2019]. Available from: http://bvsms.saude.gov.br/bvs/publicacoes/ politica_nacional_atencao_saude_homem.pdf

14. Vilela RAG, Laat EF, Luz VG, Silva AJN, Takahashi MAC. Pressão por produção e produção de riscos: a "maratona" perigosa do corte manual da canade-açúcar. Rev Bras Saúde Ocup. [Internet]. 2015 [Acesso 14 fev 2020];40(131):30-48. Disponível em: http://www.scielo.br/scielo.php?pid=S030376572015000100030\&script=sci_abstract\&tlng=pt.

15. Rosa LA, Navarro VL. Trabalho e trabalhadores dos canaviais: perfil dos cortadores de cana da região de Ribeirão Preto (SP). Cad Psicol Soc Trab. [Internet]. 2015 [Acesso 12 mar 2017];17(1):143-60. Disponível em: http://www.revistas.usp.br/cpst/article/view/112338.

16. Prado GF, Zanetta DM, Arbex MA, Braga AL, Pereira LA, Marchi MR, et al. Burnt sugarcane harvesting: particulate matter exposure and the effects on lung function, oxidative stress, and urinary 1-hydroxypyrene. Sci Total Environ. [Internet]. 2012 [cited 2016 Dez, 20];437: 200-8. Available from: https://www.sciencedirect.com/ science/article/pii/S0048969712010145?via\%3Dihub

17. Laws RL, Brooks DR, Amador JJ, Weiner DE, Kaufman JS, Ramirez-Rubio O, et al. Changes in kidney function among Nicaraguan sugarcane workers. Int J Occup Environ Health. [Internet]. 2015 [cited 2017 Jan 15];21(3):241-50. Available from: https://www.ncbi. nlm.nih.gov/pmc/articles/PMC4597013

18. Messias IA, Okuno E. Study of postures in sugarcane cutters in the Pontal of Paranapanema-SP, Brazil. Work. [Internet]. 2012 [cited 2017 Feb 10];41 Suppl 1:5389-91. Avaiable from: https://content.iospress.com/download/ work/wor0828?id=work\%2Fwor0828

19. Castro Rocha DFN, Cunha Rosa LR, Almeida Silva C, Oliveira BR, Martins TLS, Martins RMB, et al. Epidemiology of HIV, syphilis, and hepatitis $B$ and $C$ among manual cane cutters in low-income regions of Brazil. BMC Infect Dis. 2018 Nov;18(1):546. doi: https://doi.org/10.1186/ s12879-018-3439-4

20. Novacana As usinas de açúcar e etanol do Brasil. [Internet]. 2017. [cited 2017 Nov 30]. Avaiable from: https://www.novacana.com/usinas_brasil 
21. Ministério da Saúde (BR). Boletim Epidemiológico HIV/AIDS. [Internet]. 2015. Disponível em: http://www. aids.gov.br/pt-br/pub/2015/boletim-epidemiologicohivaids-2015

22. Ministério da Saúde (BR). Pesquisa de conhecimentos, atitudes e práticas na população brasileira. [Internet]. 2011. Disponível em: http://bvsms.saude.gov.br/bvs/ publicacoes/pesquisa_conhecimentos_atitudes_praticas_ populacao_brasileira.pdf

23. Hosmer DW, Lemeshow S. Applied logistic regression. $2^{\text {nd }}$ ed. New Jersey: John Wiley \& Sons; 2000.

24. Brasil. Conselho Nacional de Saúde. Resolução no 466, de 12 de dezembro de 2012. Diretrizes e normas regulamentadoras de pesquisas envolvendo seres humanos. [Internet]. Disponível em: https://bvsms.saude.gov.br/bvs/ saudelegis/cns/2013/res0466_12_12_2012.html

25. Soares RAS, Moraes RM, Vianna RPT, Pessoa VM, Carneiro FF. Determinantes socioambientais e saúde: o Brasil rural versus o Brasil urbano. [Internet]. Tempus Actas Saúde Colet. 2015;9(2):221-35. Disponível em: http://www.tempusactas.unb.br/index.php/tempus/ article/view/1718/1440

26. Carvalho LCS Junior, Ramos EMC, Toledo AC, Ceccato ADF, Macchione M, Braga ALF, et al. Assessment of healthrelated quality of life sugar cane cutters in the pre-havest and harvest periods. [Internet] Rev Saúde Públ. 2012 [cited $2017 \mathrm{Jul} 10]$; 46(6):1058-65. Available from: https://www. researchgate.net/publication/236056079_Assessment_ of_healthrelated_quality_of_life_of_sugarcane_cutters_ in_the_pre-harvest_and_harvest_periods

27. Luz VG, Zangirolani LTO, Vilela RAG, Corrêa Filho HR. Consumo alimentar e condições de trabalho no corte manual de cana de açúcar no estado de São Paulo. Saude Soc. [Internet]. 2014 [Acesso 19 fev 2020];23(4):1316-28. Disponível em: http://www.scielo.br/scielo.php? script=sci_arttext\&pid=S0104-12902014000401316

28. Moraes MS, Lopes JCC, Priuli RMA. Questões socioeconômicas, laborais e de saúde na cadeia produtiva do agronegócio da cana-de-açúcar na região do Noroeste Paulista. Saude Soc. [Internet]. 2013 Sep

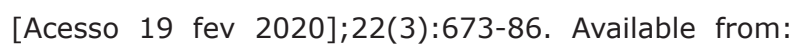
http://www.scielo.br/scielo.php?pid=S0104129020130 $00300003 \&$ script $=$ sci_abstract $\&$ tlng $=p t$

29. Miranda $A E$, Ribeiro $D$, Rezende EF, Pereira GFM, Pinto VM, Saraceni V. Associação de conhecimento sobre DST e grau de escolaridade entre conscritos em alistamento ao Exército Brasileiro. Brasil, 2007. Ciênc Saúde Coletiva. [Internet]. 2013 [Acesso $19 \mathrm{fev} \mathrm{2020];18(2):489-97.}$ Disponível em: http://www.scielo.br/scielo.php?pid=S141381232013000200020\&script $=$ sci_abstract\&tIng=pt

30. Fontes MB, Crivelaro RC, Scartezini AM, Lima DD, Garcia AA, Fujioka RT. Fatores determinantes de conhecimentos, atitudes e práticas em DST/Aids e hepatites virais, entre jovens de 18 a 29 anos, no Brasil. Ciênc Saúde Coletiva. [Internet]. 2017 [Acesso $19 \mathrm{fev}$ 2020];22(4):1343-52. Disponível em: http://www. scielo.br/scielo.php?pid=S1413-81232017002401343\& script $=$ sci_abstract\&tIng $=$ pt

31. Mutagoma M, Remera E, Sebuhoro D, Kanters S, Riedel DJ, Nsanzimana S. The prevalence of syphilis infection and its associated factors in the general population of Rwanda: a national household-based survey. J Sex Transm Dis. 2016;2016:4980417. doi: https://doi.org/10.1155/2016/4980417

32. Chen L, His JH, Wu X, Shen Z, Lu H, Chen H, et al. Disparities in HIV and syphilis prevalence and risk factors between older male clients with and without steady sex partners in southwestern rural China. BMC Infect Dis. 2017 Apr;17(1):269. doi: https://doi.org/10.1186/ s12879-017-2367-z

33. Melo LVL, Silva MAB, Perdoná GSC, Nascimento MMP, Secaf M, Monteiro RA et al. Epidemiological study of hepatitis $B$ and $C$ in a municipality with rural characteristics: Cássia dos Coqueiros, State of São Paulo, Brazil Rev Soc Bras Med Trop. [Internet]. 2015 Dec [cited 2020 Feb 19];48(6):674-81. Available from: http://www.scielo.br/scielo.php?script=sci_ arttext\&pid $=$ S0037-86822015000600674

34. Barbosa KF, Batista AP, Nacife MBPSL, Vianna VN, Oliveira WW, Machado EL et al. Fatores associados ao não uso de preservativo e prevalência de HIV, hepatites virais B e C e sífilis: estudo transversal em comunidades rurais de Ouro Preto, Minas Gerais, entre 2014 e 2016. Epidemiol Serv Saúde [Internet]. 2019 [Acesso $19 \mathrm{fev}$ 2020];28(2):e2018408. Disponível em: http://www. scielo.br/scielo.php?script=sci_arttext\&pid=S223796222019000200318\&lang=pt

35. Monsell E, McLuskey J. Factors influencing STI transmission in middle-aged heterosexual individuals. Br J Nurs. 2016 Jun;25(12):676-80. doi: https://doi. org/10.12968/bjon.2016.25.12.676

36. August EM, Daley E, Kromrey J, Baldwin J, RomeroDaza N, Salmeron J, et al. Age-related variation in sexual behaviours among heterosexual men residing in Brazil, Mexico and the USA. J Fam Plann Reprod Health Care. 2014 Oct;40(4):261-9. doi: http://dx.doi.org/10.1136/ jfprhc-2012-100564

37. Hojilla JC, Marcus J, Volk JE, Leyden W, Hare CB, Hechter RC, et al. Alcohol and drug use, partner PrEP use and STI prevalence among people with HIV. Sex Transm Infect. 2019 Aug 23. doi: 10.1136/sextrans-2019-054049 38. Harbertson J, Scott PT, Lemus H, Michael NL, Hale BR. Cross-sectional study of sexual behavior, alcohol use, and mental health conditions associated with sexually transmitted infections among deploying shipboard US military personnel. Mil Med. 2019 Dec;184(11-12):e693-700. doi: https://doi. org/10.1093/milmed/usz070 
39. Domingos R. Cortadores de cana de SP contam dramas após vício de crack. [Internet]. 2011 [Acesso em 10 jul 2017]. Disponível em: http://g1.globo.com/ sao-paulo/noticia/2011/09/cortadores-de-cana-de-spcontam-dramas-apos-vicio-no-crack.html.

40. Neves RG, Wendt A, Flores TR, Costa CS, Costa FS, Tovo-Rodrigues $L$, et al. Simultaneidade de comportamentos de risco para infecções sexualmente transmissíveis em adolescentes brasileiros, 2012. Epidemiol Serv Saúde. [Internet]. 2017 [Acesso 19 fev 2020]; 26(3):443-54. Disponível em: http://www. scielo.br/scielo.php?script=sci_abstract $\&$ pid $=$ S223796222017000300443\&lng=en\&nrm=iso\&t/ng=pt

41. Lomba L, Apostolo J, Loureiro H, Graveto J, Silva M, Mendes F. Consumos e comportamentos sexuais de risco na noite de Coimbra. Rev Toxicodependências. [Internet] 2008 [Acesso mar 2017];14(1):31-41. Disponível em: http://www.irefrea.eu/uploads/PDF/Lombaetal_2008.pdf 42. Marendaz E. Vida sexual e a religião batista: um olhar gestáltico. Revista IGT na Rede. [Internet] 2016 [Acesso 22 nov 2018];13(25)323-9. Disponível em: http://pepsic.bvsalud.org/pdf/igt/v13n25/v13n25a9.pdf 43. Mojahed A. Religiosity and preventing risky behaviors Int J High Risk Behav Addict. 2014 Sep;3(3):e22844. doi: 10.5812/ijhrba.22844

44. Ameri Z, Mirzakhani F, Nabipour AR, Khanjani N, Sullman MJM. The relationship between religion and risky behaviors among Iranian university students. J Relig Health. 2017 Dec;56(6):2010-22. doi: 10.1007/ s10943-016-0337-1

45. George Dalmida S, Aduloju-Ajijola N, Clayton-Jones D, Thomas TL, Erazo Toscano RJ, Lewis RJ, et al. Sexual risk behaviors of African American adolescent females: the role of cognitive and religious factors. J Transcult Nurs. 2018 Jan;29(1):74-83. doi: 10.1177/1043659616678660 46. Hoga LAK, Tiburcio CA, Borges ALV, Rebelte LM. Religiosity and sexuality: experiences of Brazilian catholic women. Health Care Women Intern. [Internet]. 2010 [cited 2018 Nov 20];13:700-17. Available from: https://www.researchgate.net/publication/260285493_ Exposure_to_and_desire_for_sexual_health_ education_among_urban_youth_Associations_with_ religion_and_other_factors

47. Shaw SA, El-Brasil N. The influence of religion on sexual HIV risk. Aids Behav. [Internet]. 2014 [cited 2018 Oct 30];18:1569-94. Available from: https://link. springer.com/article/10.1007\%2Fs10461-014-0714-2

48. Gaspar J, Quintana SS, Reis RK, Gir E. Fatores sociodemográficos e clínicos de mulheres com papilomavírus

Corresponding author:

Ana Cristina de Oliveira e Silva

E-mail: anacris.os@gmail.com

(D) https://orcid.org/0000-0001-8605-5229 humano e sua associação com o vírus da imunodeficiência humana. Rev. Latino-Am. Enfermagem. [Internet]. 2015 Feb [Acesso 19 fev 2020];23(1):74-81. Disponível em: http://www.scielo.br/scielo.php?pid=S010411692015000100074\&script=sci_abstract\&tIng=pt

49. Lagarde E, Caraël M, Glynn JR, Kanhonou L, Abega SC, Kahindo M, et al. Educational level is associated with condom use within non-spousal partnerships in four cities of sub-Saharan Africa. AIDS. 2001 Jul 27;15(11): 1399-408. doi: 10.1097/00002030-200107270-00009
Received: Jul 11th 2019

Accepted: Mar 20th 2020

Associate Editor:

Ricardo Alexandre Arcêncio

Copyright $\odot 2020$ Revista Latino-Americana de Enfermagem This is an Open Access article distributed under the terms of the Creative Commons (CC BY).

This license lets others distribute, remix, tweak, and build upon your work, even commercially, as long as they credit you for the original creation. This is the most accommodating of licenses offered. Recommended for maximum dissemination and use of licensed materials. 